\title{
Ethnic differences in lung function in Israeli children
}

Hector Roizin, Amir Szeinberg, Elvan Tabachnik, Morico Molho, Shlomo Benzaray, Arie Augarten, Dov Har-Even, Zohar Barzilay, Jacob Yahav

\begin{abstract}
Background-The population of Israel consists of immigrants from many different countries. It is not known whether a single nomogram can be used for spirometric values of children of different ethnic descent.

Methods-Spirometry was performed in 753 second or third generation Israeli children (7-14 years) of different ethnic groups. Both parents of 503 of the children were of the same ethnic background. Subjects were allocated to six ethnic groups (European, Iraqi, North African, Indian, Yemenite, and Georgian).

Results-Standing height contributed most to the prediction of spirometric values (forced expiratory volume in one second, forced vital capacity), whereas sitting height did not contribute further. Statistical analysis showed significant ethnic differences. The Georgians had higher spirometric values for $\mathrm{FEV}_{1}$ than all the other ethnic groups, and higher FVC values than those of the Yemenite, North African, and Indian groups. FVC was lower among the Indian than all other groups.

Conclusion-Differences in normal spirometric values were found among second or third generation Israeli children of different ethnic origins. European, North African, Iraqi, and Yemenite children could be characterised by single equation, whereas children of Georgian and Indian descent needed different predicting equations.
\end{abstract}

(Thorax 1993;48:906-910)

Division of

Paediatrics and

Pulmonary Function

Institute,

Chaim Sheba Medical

Centre, Tel Hashomer

56261, Israel

H Roizin

A Szeinberg

E Tabachnik

M Molho

S Benzaray

A Augarten

D Har-Even

Z Barzilay

J Yahav

Reprint requests to:

Dr A Szeinberg

Received 7 October 1991

Returned to authors

10 December 1991

Revised version received

9 February 1993

Accepted 9 June 1993 low levels of ventilatory function in men born $\overrightarrow{0}$ in Asia and North Africa when compared $\overrightarrow{\vec{\omega}}$ with white North American men. ${ }^{16}$ Goren et $\stackrel{\omega}{S}$ al reported low lung function values among $\overrightarrow{\vec{x}}$ immigrants from Iraq/Iran, whereas subjects from Morocco had similar values to those of European descent. ${ }^{15}$

We assessed differences in lung function among second or third generation Jewish 은 children of different ethnic origins living in $\vec{c}$ Israel. Genetic predisposition rather than $\mathbb{D}$ environmental influences should therefore be more likely to account for any differences found.

\section{Methods}

The study population included 912 Jewish children from five elementary schools around Tel Aviv. The principals of the schools were approached after receiving permission from $\stackrel{\unrhd}{\unrhd}$ the Israeli board of education, and the $\overrightarrow{\vec{F}}$ approval of the Chaim Sheba Medical $\frac{0}{3}$ Centre's Helsinki committee. The classes studied were selected by the principals of the schools. The teacher of each class received general information about and a detailed explanation of the procedures of the study. The paediatrician conducting the study (HR) met each class and instructed the pupils. Each participant received a letter of explanation to their parents to obtain their signed permission together with a questionnaire on the ethnic origin of both parents and grand- $\frac{7}{2}$ parents and on the child's health status. Seven hundred and fifty three parents gave $\mathscr{N}$ their approval, eight refused, and 151 did not $N$ respond at all. The 753 children who partici- N pated in the study filled in a medical history questionnaire, ${ }^{17}$ which was translated into 0 Hebrew and modified for children. Data from $\varnothing$ the children's school medical records were $\stackrel{?}{+}$ used to ascertain previous health status. In $\frac{7}{\circ}$ addition, each of the pupils was interviewed $\frac{O}{\mathbb{D}}$ about medical history and smoking status, and a physical examination was carried out by $\stackrel{2}{2}$ one of us (HR). Exclusion criteria included any evidence of previous or concurrent 8 cardiorespiratory disease (particularly any history of wheezing), spinal deformity or any 흘 other major disease, and inability to perform technically satisfactory spirometric tests. However, all 753 pupils who were examined performed the tests to prevent embarrassment among peers.

Forced expiratory volume in one second, 
forced vital capacity, and their ratio were measured according to the recommendations of the American Thoracic Society's Snowbird committee $^{18}$ by one investigator (HR) using a wedge spirometer (Vitalograph, Buckingham). The instrument was calibrated daily with a three litre syringe. After an introductory explanation of the procedure to the entire class each child was coached in the forced vital capacity manoeuvre, allowing multiple trials. The best of three satisfactory curves was chosen for analysis. In cases where the technique was unacceptable the child was re-examined a few days later. Values of $\mathrm{FEV}_{1}$ and FVC were extracted and corrected for body temperature, prevailing atmospheric pressure, and saturation of water vapour.

The following anthropometric data were obtained for each child: standing height, arm span, sitting height (crown to sacrum and C7 to sacrum), weight, mid arm circumference, and triceps skin fold thickness. Body mass index (weight/(height) ${ }^{2}$ ) and mid arm muscle circumference (mid arm circumference $3 \cdot 14 \times$ triceps skin fold thickness $)^{19}$ were calculated.

All data were analysed on an IBM 3090 system with appropriate statistical programs (SPSS-X). Lung function and anthropometric measurements were correlated with Pearson's correlation test and stepwise regression analysis. Differences between ethnic groups were examined by analysis of covariance.

Table 1 Product moment correlation between anthropometric and spirometric parameters for entire study population

\begin{tabular}{llll}
\hline & $F V C$ & $F E V_{1}$ & $F E V_{1} / F V C$ \\
\hline Weight & $0.86^{\star}$ & $0.85^{\star}$ & 0.045 \\
MAMC & $0.79^{\star}$ & $0.76^{\star}$ & 0.03 \\
Height: & & & \\
$\quad$ Standing & $0.88^{\star}$ & $0.87^{\star}$ & 0.02 \\
$\begin{array}{l}\text { Sitting: } \\
\quad \text { Crown to sacrum }\end{array}$ & $0.84^{\star}$ & $0.84^{\star}$ & 0.001 \\
$\quad$ C7 to sacrum & $0.79^{\star}$ & $0.80^{\star}$ & 0.12 \\
$\begin{array}{l}\text { Arm span } \\
\text { Body mass index } \\
\quad \text { (weight/(height) }\end{array}$ & $0.86^{\star}$ ) & $0.80^{\star}$ & 0.05 \\
Age (years) & $0.58^{\star}$ & $0.57^{\star}$ & 0.004 \\
\hline
\end{tabular}

FVC-forced vital capacity; FEV $_{1}$-forced expiratory volume in the first second; MAMC-mid arm muscle circumference. ${ }^{\star} \mathrm{p}<0.001$.

Table 2 Adjusted means (SD) of spirometric values in the different ethnic groups

\begin{tabular}{|c|c|c|c|c|c|}
\hline Ethnic origin & Sex & No & $F V C$ (l) & $F E V_{1}(l)$ & $F E V_{1} / F V C(\%)$ \\
\hline Europe & $\left\{\begin{array}{l}M \\
F\end{array}\right.$ & $\begin{array}{l}87 \\
78\end{array}$ & $\begin{array}{l}2 \cdot 437(0.677) \\
2 \cdot 338(0.618)\end{array}$ & $\begin{array}{l}2 \cdot 155(0.599) \\
2 \cdot 103(0 \cdot 574)\end{array}$ & $\begin{array}{l}88 \cdot 45(4 \cdot 53) \\
90 \cdot 22(5 \cdot 95)\end{array}$ \\
\hline Iraq & $\left\{\begin{array}{l}M \\
F\end{array}\right.$ & $\begin{array}{l}22 \\
23\end{array}$ & $\begin{array}{l}2 \cdot 479(0.687) \\
2 \cdot 412(0 \cdot 697)\end{array}$ & $\begin{array}{l}2 \cdot 185(0 \cdot 517) \\
2 \cdot 199(0 \cdot 473)\end{array}$ & $\begin{array}{l}88 \cdot 36(6 \cdot 59) \\
91 \cdot 17(3 \cdot 31)\end{array}$ \\
\hline Georgia & $\left\{\begin{array}{l}M \\
F\end{array}\right.$ & $\begin{array}{l}33 \\
26\end{array}$ & $\begin{array}{l}2.535(1.052) \\
2 \cdot 436(0.697)\end{array}$ & $\begin{array}{l}2.350(0.996) \\
2.284(0.647)\end{array}$ & $\begin{array}{l}92 \cdot 05(4 \cdot 21) \\
93 \cdot 40(5 \cdot 27)\end{array}$ \\
\hline North Africa & $\left\{\begin{array}{l}\mathbf{M} \\
\mathbf{F}\end{array}\right.$ & $\begin{array}{l}29 \\
33\end{array}$ & $\begin{array}{l}2 \cdot 353(0 \cdot 616) \\
2 \cdot 238(0 \cdot 641)\end{array}$ & $\begin{array}{l}2 \cdot 104(0 \cdot 513) \\
2 \cdot 066(0 \cdot 603)\end{array}$ & $\begin{array}{l}89 \cdot 41(4 \cdot 67) \\
92 \cdot 75(6.92)\end{array}$ \\
\hline India & $\left\{\begin{array}{l}M \\
F\end{array}\right.$ & $\begin{array}{l}21 \\
31\end{array}$ & $\begin{array}{l}2 \cdot 166(0 \cdot 434) \\
2 \cdot 148(0 \cdot 614)\end{array}$ & $\begin{array}{l}1.974(0.355) \\
2.010(0.593)\end{array}$ & $\begin{array}{l}92 \cdot 10(5 \cdot 48) \\
94 \cdot 38(4 \cdot 40)\end{array}$ \\
\hline Yemen & $\left\{\begin{array}{l}M \\
F\end{array}\right.$ & $\begin{array}{l}49 \\
39\end{array}$ & $\begin{array}{l}2 \cdot 342(0 \cdot 677) \\
2 \cdot 209(0 \cdot 488)\end{array}$ & $\begin{array}{l}2 \cdot 113(0 \cdot 603) \\
2 \cdot 079(0 \cdot 488)\end{array}$ & $\begin{array}{l}90 \cdot 34(4 \cdot 37) \\
94 \cdot 44(3 \cdot 65)\end{array}$ \\
\hline
\end{tabular}

For definitions of abbreviations see footnote to table 1 .

\section{Results}

Altogether 753 children aged 7-14 years were tested. Seventy nine $(10 \cdot 9 \%)$ were excluded because of a history of chest or heart disease, wheezing, or chest surgery or because of spinal deformity or concurrent upper or lower airway infection. None of the children reported a history of smoking. The results of an additional 12 children were discarded because of inadequate spirometric technique. Of the remaining 662 children, 471 were allocated to one of six ethnic groups according to the country of origin of both parents. Subjects were allotted to ethnic groups only if both parents were of the same ethnic origin. A total of 138 children were of mixed origin and their measurements were not used for interethnic comparison. Eight children of Iranian origin, 34 of Bukharic origin, and 11 of Balkan origin were also not included because of the small number of participants in these ethnic groups.

To assess the correlations between anthropometric and spirometric measures product moment correlations were computed. These correlations are presented in table 1 . Significant positive correlations were found between all anthropometric and spirometric measurements, apart from the $\mathrm{FEV}_{1} / \mathrm{FVC}$. The highest correlation coefficients found were for standing height. Moreover, stepwise regression analysis showed that standing height provided the greatest contribution to prediction of spirometric values. Addition of any other anthropometric variable, such as the ratio of sitting to standing height (the mean for the various ethnic groups ranged from 0.51 to 0.52 ), did not improve the prediction substantially.

Comparison between the various ethnic groups was done by using $6 \times 2$ analysis of covariance (ethnic by sex analysis of covariance). This analysis allows adjustment of spirometric results in relation to height, so that differences between groups would not be a function of height. Table 2 presents the adjusted means of the spirometric measurements for the six ethnic groups, separately for boys and girls. Significant differences between the ethnic groups were found on analysis of covariance (FVC $(F(5,458)$ (that is, $F$ value with degrees of freedom between and within respectively) $=11.96 ; \mathrm{p}<0.001 ; \mathrm{FEV}_{1}$ $(\mathrm{F}(5,458)=12.30 ; \quad \mathrm{p}<0.001) ; \quad \mathrm{FEV}_{1} / \mathrm{FEV}$ $(\mathrm{F}(5,458)=8 \cdot 75 ; \mathrm{p}<0.001))$.

To ascertain which of the groups contributed to these significant differences paired comparison analysis was performed with the Neuman-Keuls procedure. ${ }^{20}$ This analysis showed significant differences between the Georgian group and the other groups, the Georgians having significantly higher FEV $_{1}$ values $(p<0.001)$. The Georgians also had higher FVC values than those of the Indian, Yemenite, and North African groups $(p<0.001)$ but not significantly different values from the European and Iraqi groups. The FVC values of the Indian group were significantly lower than all the other groups $(p<0.001)$. The lower $F_{E V}$ to FVC ratios 
Table 3 Explained variance $\left(R^{2}\right)$ of $F V C, F E V_{1}$ and $F E V_{1} / F V C$ by height via linear, log-linear and log-log regression analysis in the different ethnic groups

\begin{tabular}{|c|c|c|c|c|c|c|c|c|c|c|}
\hline \multirow[b]{2}{*}{ Ethnic origin } & \multirow[b]{2}{*}{ Sex } & \multicolumn{3}{|l|}{$F V C$} & \multicolumn{3}{|l|}{$F E V_{l}$} & \multicolumn{3}{|c|}{$F E V_{1} / F V C$} \\
\hline & & Linear & Log-linear & $\log -\log$ & Linear & Log-linear & $\log -\log$ & Linear & Log-linear & $\log -\log$ \\
\hline Europe & $\begin{array}{l}M \\
F\end{array}$ & $\begin{array}{l}0.69 \\
0.71\end{array}$ & $\begin{array}{l}0.70 \\
0.72\end{array}$ & $\begin{array}{l}0.71 \\
0.73\end{array}$ & $\begin{array}{l}0.67 \\
0.68\end{array}$ & $\begin{array}{l}0.68 \\
0.70\end{array}$ & $\begin{array}{l}0.70 \\
0.70\end{array}$ & $\begin{array}{l}0.00 \\
0.00\end{array}$ & $\begin{array}{l}0.00 \\
0.00\end{array}$ & $\begin{array}{l}0.00 \\
0.00\end{array}$ \\
\hline Iraq & & $\begin{array}{l}0.92 \\
0.81\end{array}$ & $\begin{array}{l}0.89 \\
0.83\end{array}$ & $\begin{array}{l}0.90 \\
0.82\end{array}$ & $\begin{array}{l}0.90 \\
0.79\end{array}$ & $\begin{array}{l}0.86 \\
0.81\end{array}$ & $\begin{array}{l}0.87 \\
0.81\end{array}$ & $\begin{array}{l}0.11 \\
0.01\end{array}$ & $\begin{array}{l}0.12 \\
0.01\end{array}$ & $\begin{array}{l}0.11 \\
0.01\end{array}$ \\
\hline Georgia & & $\begin{array}{l}0.82 \\
0.76\end{array}$ & $\begin{array}{l}0.86 \\
0.75\end{array}$ & $\begin{array}{l}0.86 \\
0.75\end{array}$ & $\begin{array}{l}0.81 \\
0.80\end{array}$ & $\begin{array}{l}0.87 \\
0.80\end{array}$ & $\begin{array}{l}0.87 \\
0.80\end{array}$ & $\begin{array}{l}0.02 \\
0.01\end{array}$ & $\begin{array}{l}0.02 \\
0.01\end{array}$ & $\begin{array}{l}0.02 \\
0.01\end{array}$ \\
\hline $\begin{array}{l}\text { North } \\
\text { Africa }\end{array}$ & & $\begin{array}{l}0.62 \\
0.72\end{array}$ & $\begin{array}{l}0.62 \\
0.76\end{array}$ & $\begin{array}{l}0.63 \\
0.77\end{array}$ & $\begin{array}{l}0.65 \\
0.77\end{array}$ & $\begin{array}{l}0.66 \\
0.82\end{array}$ & $\begin{array}{l}0.66 \\
0.82\end{array}$ & $\begin{array}{l}0.03 \\
0.02\end{array}$ & $\begin{array}{l}0.03 \\
0.02\end{array}$ & $\begin{array}{l}0.03 \\
0.01\end{array}$ \\
\hline India & & $\begin{array}{l}0.52 \\
0.81\end{array}$ & $\begin{array}{l}0.53 \\
0.86\end{array}$ & $\begin{array}{l}0.54 \\
0.85\end{array}$ & $\begin{array}{l}0.46 \\
0.78\end{array}$ & $\begin{array}{l}0.48 \\
0.84\end{array}$ & $\begin{array}{l}0.50 \\
0.84\end{array}$ & $\begin{array}{l}0.15 \\
0.00\end{array}$ & $\begin{array}{l}0.15 \\
0.00\end{array}$ & $\begin{array}{l}0 \cdot 15 \\
0 \cdot 00\end{array}$ \\
\hline Yemen & $\left\{\begin{array}{l}M \\
F\end{array}\right.$ & $\begin{array}{l}0.81 \\
0.79\end{array}$ & $\begin{array}{l}0.84 \\
0.81\end{array}$ & $\begin{array}{l}0.83 \\
0.82\end{array}$ & $\begin{array}{l}0.79 \\
0.79\end{array}$ & $\begin{array}{l}0.83 \\
0.81\end{array}$ & $\begin{array}{l}0.70 \\
0.71\end{array}$ & $\begin{array}{l}0.02 \\
0.07\end{array}$ & $\begin{array}{l}0.02 \\
0.07\end{array}$ & $\begin{array}{l}0.02 \\
0.06\end{array}$ \\
\hline
\end{tabular}

For definitions of abbreviations see footnote to table 1 .

among the European and Iraqi groups in comparison to the others accounted for the results of analysis of covariance. When other anthropometric measures including sitting height (crown to sacrum or C7 to sacrum), arm span, sitting to standing height ratio, weight, body mass index, and mid arm muscle circumference were used the same significant differences between the ethnic groups were found. Hence, the anthropometric measurements could not explain the

Table 4 Prediction equations of FEV 1 and FVC (in litres) on height in the different ethnic groups

\begin{tabular}{|c|c|c|c|c|}
\hline & & Intercept (a) & Slope (b) & $S E E$ \\
\hline \multirow{3}{*}{ Europe } & $\begin{array}{c}\text { FVC: } \\
\mathbf{M} \\
\mathbf{F}\end{array}$ & $\begin{array}{l}-3 \cdot 68 \\
-4 \cdot 42\end{array}$ & $\begin{array}{l}0.04 \\
0.05\end{array}$ & $\begin{array}{l}0.38 \\
0.34\end{array}$ \\
\hline & $\begin{array}{c}\mathrm{FEV}_{1}: \\
\mathbf{M}\end{array}$ & $-3 \cdot 27$ & 0.04 & 0.35 \\
\hline & $\mathbf{F}$ & $-4 \cdot 06$ & 0.04 & 0.33 \\
\hline \multirow{5}{*}{ Iraq } & FVC: & & & \\
\hline & M & -5.88 & 0.06 & 0.20 \\
\hline & & $-4 \cdot 58$ & 0.05 & 0.23 \\
\hline & $\underset{M}{\mathrm{FEV}_{1}:}$ & $-4 \cdot 10$ & 0.04 & 0.17 \\
\hline & $\mathrm{F}$ & $-4 \cdot 29$ & 0.05 & 0.22 \\
\hline \multirow{5}{*}{ Georgia } & FVC: & & & \\
\hline & $\underset{\mathbf{F}}{\mathbf{M}}$ & $\begin{array}{l}-6 \cdot 39 \\
-6 \cdot 79\end{array}$ & 0.06 & $\begin{array}{l}0.45 \\
0.35\end{array}$ \\
\hline & $\mathrm{FEV}_{1}$ : & $-6 \cdot 79$ & 0.06 & 0.35 \\
\hline & M & $-6 \cdot 11$ & 0.06 & 0.43 \\
\hline & $\mathbf{F}$ & -6.54 & 0.06 & 0.30 \\
\hline \multirow{5}{*}{ North Africa } & FVC: & & & \\
\hline & $M$ & $-4 \cdot 25$ & 0.05 & 0.38 \\
\hline & $\begin{array}{c}\mathrm{F} \\
\mathrm{FEV}_{1}\end{array}$ & $-3 \cdot 64$ & 0.04 & 0.34 \\
\hline & M & -3.56 & 0.04 & 0.31 \\
\hline & $\mathrm{F}$ & -3.65 & 0.04 & 0.29 \\
\hline \multirow{5}{*}{ India } & FVC: & & & \\
\hline & $\mathbf{M}$ & $-2 \cdot 37$ & 0.03 & 0.31 \\
\hline & $\mathbf{F}$ & $-4 \cdot 12$ & 0.04 & 0.27 \\
\hline & $\mathrm{FEV}_{1}:$ & -1.52 & 0.02 & 0.27 \\
\hline & $\mathbf{F}$ & -3.96 & 0.04 & 0.28 \\
\hline \multirow{5}{*}{ Yemen } & FVC: & & & \\
\hline & $\begin{array}{l}\mathbf{M} \\
\mathbf{F}\end{array}$ & $\begin{array}{l}-4 \cdot 53 \\
-3 \cdot 38\end{array}$ & $\begin{array}{l}0.05 \\
0.04\end{array}$ & $\begin{array}{l}0.30 \\
0 \cdot 22\end{array}$ \\
\hline & $\mathrm{FEV}_{1}$ : & & & \\
\hline & $\mathbf{M}$ & -3.94 & 0.04 & 0.28 \\
\hline & $\mathbf{F}$ & $-3 \cdot 47$ & 0.04 & 0.22 \\
\hline
\end{tabular}

SEE-standard error of the estimate; index-intercept + (slope $\times$ height $)$.

For definition of other abbreviations see footnote to table 1 . interethnic variability in spirometric values.

Analysis of covariance showed significant 0 differences between boys and girls for FVC $(\mathrm{F}(1,458)=13.59 ; \mathrm{p}<0.001), \mathrm{FEV}_{1} / \mathrm{FVC}$ क $(\mathrm{F}(1,458)=25.64 ; \mathrm{p}<0.001)$ but not for $\mathrm{FEV}_{1}(\mathrm{~F}(1,458)=2 \cdot 76 ; \mathrm{p}>0 \cdot 05)$. From table $\frac{\mathbb{D}}{3}$ 2 it can be seen that for all the ethnic groups FVC was higher in the boys and $\mathrm{FEV}_{1} / \mathrm{FVC}_{-}$ higher in the girls. The analysis of covariance $\stackrel{E}{e}$ did not show any significant interaction effect $\omega$ of ethnic by sex, thus the differences between the ethnic groups are consistent for boys and girls.

To establish prediction equations of the spirometric measures on height, three kinds $\frac{\circ}{\mathbb{D}}$ of regression analysis were performed: linear, $\log$-linear, and $\log -\log { }^{21}$ with $\mathrm{FEV}_{1}, \mathrm{FVC}$, and $F E V_{1} / F V C$ as dependent variables. Table 3 presents the explained variance $\left(R^{2}\right)$ for these regression analyses. A linear relation holds for $\mathrm{FEV}_{1}$ and FVC but not for $\mathrm{FEV}_{1} / \mathrm{FVC}$, and linearity was not improved by $\log$-linear or $\log$-log transformations. $R^{2} \dot{\sigma}$ for the three kinds of regressions did not differ substantially from each other, and the 0 additional contribution of $\log$-linear and $\log$-log equations in comparison to linear is minimal. In addition, the differences in $R^{2}$ 要 between boys and girls were inconsistent between the races. There was a pronounced $N$ sex difference in Indians, $\mathbf{R}^{2}$ being lower for $N$ boys and girls, moderate differences among N Iraqis, Georgians, and North Africans, and ${ }_{\sigma}^{\omega}$ only slight differences among European and Yemenite children. Table 4 presents the lin- $\frac{-}{\Phi}$ ear prediction equations for $\mathrm{FEV}_{1}$ and $\mathrm{FVC} \stackrel{?}{?}$ on height.

\section{Discussion}

We found significantly different spirometric무 values among children from different ethnic 0 Jewish groups in Israel. In Georgian childreno $\mathrm{FEV}_{1}$ values were higher than in all other groups; their FVC measurements were also significantly higher than those of the Indians, Yemenites, and North Africans but similar to those of the other groups. In the Indian group the FVC was significantly lower than in all other ethnic groups. 
Previous studies of the effect of ethnicity on lung function in Israel have been contradictory. Schlesinger et al showed low spirometric values in immigrants from North Africa, but this study related only to men over 40 who were born in their country of origin and immigrated to Israel as adults. ${ }^{16}$ Carel et al in a survey of navy cadets did not find any significant differences among ethnic groups. ${ }^{22}{ }^{23}$ They stratified their subjects into only three groups: Ashkenazi, Sephardic, and second generation Israelis. The Sephardic group included immigrants of both Asiatic and African origin without any further subdivision. We examined children descended from immigrants from several different regions who were growing up in Israel, and we found more distinct variability.

Interestingly, the low FVC values found in Jewish children of Indian descent were also observed in studies conducted in Nottingham in local children of Indian descent. ${ }^{24}{ }^{25}$ Like us, the authors were unable to explain the differences found by anthropometric measurements or by environmental factors.

In our current study anthropometric measurements could not explain the interethnic variability in spirometric values. In previous studies differences in volume between black and white populations have been accounted for by differences in the sitting to standing height ratio..$^{51026}$ In a recent study in Israel of Ethiopian Jewish immigrants sitting to standing height ratios were found to be relatively low $(0 \cdot 48),{ }^{10}$ which accounted for the low lung volumes as predicted by nomograms based on standing height. The sitting to standing height ratios of the different ethnic groups in our study varied within a narrow range $(0.51-0.52)$ and therefore it is not surprising that these ratios could not explain the differences in ventilatory function. Thus sitting to standing height ratio may be more crucial in explaining the variability between black and white populations than the variation between white populations of different ethnic origin.

The variability of FVC and FEV was best $_{1}$ accounted for by standing height. Our findings agree with those of previous studies in children, in which $\mathrm{FEV}_{1} / \mathrm{FVC}$ was not related to anthropometric measurements ${ }^{12}$ and no significant ethnic variability in $\mathrm{FEV}_{1} / \mathrm{FVC}$ was shown. ${ }^{2425}$

The variability between ethnic groups with relation to paediatric spirometric values, which was elicited in the present study, could be due to ethnic differences in growth velocity, which have been reported. Height velocity in Chinese children aged 4-6 years was significantly lower than Tanner's reference values, ${ }^{27}$ whereas in aboriginal Australian babies aged 1-3 months growth velocity exceeded international reference values. ${ }^{28}$ Therefore, if the differences in spirometric values are due to ethnic variability in growth velocity then they might be expected to disappear once adulthood is achieved.

Several kinds of regression equations are used in published work suggesting that a $\log -\log$ or a $\log$-linear regression could fit better than a linear regression for the prediction of spirometric measurements. We found that the differences between the regression equations are not substantial or consistent among the various ethnic groups studied (table 3). The linear nature of the regression equations in our data may be because the children were comparatively young. However, differences between sexes were found, independent of ethnicity, as has been observed by others. 89121424

Although ethnic differences are apparent in Israel, our study suggests that spirometric values in children of European, North African, Iraqi, and Yemenite origin are not significantly different. For clinical application children from these ethnic groups can share a single nomogram for spirometric values. Children of Georgian and Indian descent need to be characterised by different prediction equations.

This study is part of a thesis in basic science by HR.

1 Michaelson ED, Watson H, Silva G, Zapata A, SerafiniMichaelson SM, Sackner MA. Pulmonary function in normal children. Bull Eur Physiopathol Respir 1978; 14.525-50.

2 Pistelli G, Paci A, Dalle Luche A, Giuntini C. Pulmonary volumes in children. II. Normal values in female children 6 to 15 years old. Bull Eur Physiopathol Respir 1978;14:513-23.

3 Foster JH, Hsieh PL. The vital capacity of the Chinese: an occupational study. Arch Intern Med 1923;32:332-42.

4 Wilson MG, Edwards DJ. Diagnostic value of determining vital capacity of lung of children. $\mathfrak{F A M A} 1992$; 78: 1107 .

5 Smillie WG, Augustine DL. Vital capacity of the Negro race. $¥ A M A$ 1926;87:2055-8.

6 Lapp NL, Amandus HE, Hall R, Morgan WKC. Lung volumes and flow rates in black and white subjects. Thorax 1974;29:185-8.

7 Binder RE, Mitchell CA, Schoenberg JB, Bouhuys A Lung function among Black and white children. Am Rev Respir Dis 1976;114:955-8.

8 Dockery W, Berky CS, Ware JH, Speizer FE, Ferris BG Jr. Distribution of forced vital capacity and forced expiratory volume in one second in children 6 to 11 years of age. Am Rev Respir Dis 1983;128:405-12.

9 Hsu KHK, Jenkins DE, Hsi BP, Bourhofer E, Thompson V, Tanakawa N, Hseih GSJ. Ventilatory functions of normal children and young adults Mexican-American, white and black. I. Spirometry. F Pediatr 1979;95:14-23.

10 Bibi H, Goldsmith JR, Vardi H. Racial or ethnic variation in spirometric lung function norms. Recommendation based on study of Ethiopian Jews. Chest 1988; 93:1026-30

11 Asher IM, Douglas L, Stewart AW, Quinn JP, Hill PM. Lung volumes in Polynesian children. Am Rev Respir Dis 1987; 136:1360-5.

12 Shamssain $\mathrm{MH}$, Thompson J, Ogston SA. Forced expiratory indices in normal Libyan children aged 6-19 years. Thorax 1988;43:467-70.

13 Miller GJ, Saunders MJ, Gilson RJC, Ashcroft MT. Lung function of healthy boys and girls in Jamaica in relation to ethnic composition, test exercise performance, and habitual physical activity. Thorax 1977;32:486-96.

14 Ayub M, Zaidi SH, Burki NK. Spirometry and flow-volume curves in healthy, normal Pakistanis. $\mathrm{Br} f \mathrm{Dis}$ Chest 1987;81:35-44.

15 Goren AI, Bruderman I. Pulmonary functions and respiratory symptoms and diseases among adult Israelis. Isr $\mathcal{F}$ Med Sci 1986;22:761-5.

16 Schlesinger Z, Goldbourt U, Medalie JH, Riss E, Neufeld $\mathrm{HN}$, Oron D. Pulmonary function and respiratory disease among adult male Israelis. Isr $\mathscr{f} \mathrm{Med} S \mathrm{Sc}$ 1972;8:957-64.

17 Ferris BG. Epidemiology standardization project II Recommended respiratory disease questionnaire for use with adults and children in epidemiological research. Am Rev Respir Dis 1978;118:7-53.

18 Gardner RM, Chairman. ATS Statement on Snowbird workshop on standardization of spirometry. Am Rev Respir Dis 1979;119:831-8. 
19 Frisancho AR. Triceps skinfold and upper arm muscle size norms for assessment of nutritional status. $\mathrm{Am} \mathcal{F}$ Clin Nutr 1974;27:1052-7.

20 Winer BJ. Statistical principles in experimental design. 2nd ed. New-York: McGraw-Hill, 1971:191-5.

21 Quanjer PhH, Stocks J, Polgar G, Wise M, Karlberg J Borsboom G. Compilation of reference values for lung function measurements in children. Eur Respir $\mathcal{F}$ 1989;2(suppl 4)184-261s.

22 Carel RS, Greenstein A, Ellender E, Melamed Y, Kerem D. Factors affecting ventilatory lung function in young Navy selectees. Am Rev Respir Dis 1983;128:249-52.

23 Carel RS, Bogard H, Ehrlich D. Spirometric lung function in Israeli males. Harefuah 1982;102:191-4.

24 Patrick JM, Patel A. Ethnic differences in the growth of lung function in children: a cross-sectional study in inner-city Nottingham. Ann Hum Biol 1986;13:307-15. 25 Johnston IDA, Bland JM, Anderson HR. Ethnic variation in respiratory morbidity and lung function in childhood Thorax 1987;42:542-8.

26 Hsi BP, Hsu KHK, Jenkins DE. Ventilatory function of normal children and young adults: Mexican-American, white and black. III. Sitting height as a predictor. f Pediatr 1983;102:860-5.

27 Liang SF, Dai WZ. A growth velocity standard for Chinese children in Hong Kong. Chin Med $\mathcal{f}$ [Engl] 1989;102:233-5.

28 Gracey M, Sullivan H. Growth of aboriginal infants in the first year of life in remote communities in north-west Australia. Ann Hum Biol 1988;15:375-82. 